\title{
Socio Economic Determinants of Poverty Status Among Ginger Farmers in Southern Kaduna, Nigeria
}

\author{
$\begin{array}{lll}\text { C.C. } \text { Ezeh }^{1} \quad \text { D.F. Omokore } & \text { O.H. Ezeh } \\ & & \end{array}$ \\ 1.College of Agriculture, Ahmadu Bello University, Zaria. \\ 2.Department of Agricultural Extension and Rural Development, Ahmadu Bello University, Zaria. \\ 3.Department of Community Medicine. Ahmadu Bello University, Zaria
}

\begin{abstract}
Poverty in Nigeria is pervasive, endemic and is predominantly so in the rural areas where majority of the households are farmers. This study was conducted in the Southern parts of Kaduna State covering three Local Government Areas (LGAs); Kachia, jaba and Kagarko, to determine the factors that influence poverty and its intensity among ginger farmers. Multi stage sampling procedure was used to select the 3 LGAs, 9 wards and 440 respondents. Data were generated using a structured questionnaire. Descriptive and inferential statistics were used to analyze the data. The results showed that over $56 \%$ of the respondents fell below the poverty line of \$684 (US\$ 1.90 ) per day. The results also revealed that the poverty gap index was $41.71 \%$ while the poverty severity index was $29.40 \%$. Major factors that significantly determined the poverty status of the respondents were level of education, farm income and dependency ratio, while only farm income and dependency ratio significantly $(\mathrm{P}<0.01)$ influenced the intensity of poverty. Inadequate capital, poor pricing of produce and delays in the supply of inputs and credit were among major constraint identified. Recommendations were proffered to include the formation and membership of cooperative and farmers groups.
\end{abstract}

Key words: Determinants poverty status ginger farmers.

DOI: $10.7176 / \mathrm{JESD} / 10-8-02$

Publication date: April $30^{\text {th }} 2019$

\section{Introduction}

In the last two decades, poverty has become an important topic for discussion among world leaders, both of poor and rich countries. Not surprising, this is because poverty has assumed a very visible part of human society affecting nations, regions and individuals. According to Sachs (2005), every civilization has its class of the poor; those marginalized from society and its resources by culture, ideology and power. Though a global problem, poverty has been aggravated in third world countries by their slow or stagnant development, political instability, wars, famine and environmental challenges like drought and floods (World Bank, 2015).

Poverty is a negative analogue of human development. It has many faces, changing from place to place and across time, and has been described in many ways. In its most general sense, poverty is the lack of basic necessities; food, shelter, medical care and safety which are generally thought necessary based on shared values of human dignity (Bradshaw, 2005). According to Suharko (2007), the poor struggle daily for survival; they suffer from lack of nutrition, health water and sanitation and other basic needs of life.

In Nigeria, poverty is pervasive and endemic. The incidence of poverty was estimated at $53.5 \%$ with poverty levels deeper and more severe in the rural areas in 2015 (World Bank, 2015). Incidentally, Nigeria's economy is characterized by large agricultural based tradition that encompasses about two-thirds of the population living in poverty (Thomas and Canagourajah, 2008). Affirming this viewpoint further, the World Bank (2015) posited that over $70 \%$ of the rural population in Nigeria is poor. Literature is replete with evidence that poverty is a major problem among the rural population of which farmer constitute about 70\% (Omonona, 2009; Omobowale, 2014). The 2012 MDG Report showed that $32 \%$ of the population live in extreme poverty while as much as $54 \%$ are poor in relative terms.

The areas where the poor live are mostly characterized by bad roads making them to lack access to productive inputs as well as the output market and other facilities like health clinics/hospitals, potable water and electricity (Ugwuanyi and Chukwuemeka, 2013). Furthermore, according to Onmonona (2009); these rural households have small sized farms, use traditional farming inputs and face food insecurity during the rains just before harvest; a period characterized by the simultaneous prevalence of malnutrition (as diets are limited to starch based ones), poor food availability, sickness, indebtedness, hard work and discomfort.

Ginger is cultivated in different parts of Nigeria, though the major producing areas include Kaduna, Nassarawa, Sokoto, Zamfara, Akwa Ibom, Oyo, Abia and Lagos States. However, the southern part of Kaduna State is the largest producer of ginger in Nigeria with concentration in Kachia, Jaba, Jama'a and Kagarko LGAs (KADP, 2004). In recent times, interest and demand for ginger have increased tremendously worldwide and the crop has assumed great importance (Egbuchua and Enujeke, 2013). According to Ihuoma and Dogara (2018), ginger production in Kaduna State is one of the economic activities that could serve as a source of employment, 
revenue generation and poverty alleviation. Noteworthy on poverty alleviation, is the fact that Kaduna state government has embarked on a number of programmes aimed at increasing productivity and empowering ginger farmers, including the Root and Tuber production Expansion Programme (RTPEP).

Evidently, in spite of the several interventions by the government and non-governmental organization (NGOs), ginger production is predominantly carried out by small scale operators who cultivated less than half a hectare per year (Ihuama and Dogara, 2013). Also, it has been estimated that ginger production efficiency has been very low with an estimated yield of only 5 tons per hectare in Nigeria of fresh ginger compared to China and India were yields range between 10 and 15 tons per hectare depending on the variety (Mailumo et al, 2014). With the low yield and other challenges faced by ginger farmers in Southern Kaduna, it is important to examine how financially empowered or otherwise they are and what factors influence their poverty status.

The objectives of the study were to:

i. describe the socio-economic characteristics of the ginger farmers in the study area,

ii. determine the poverty status of the farmers,

iii. determine the influence of socio-economic variables on the poverty status,

iv. identify the constraints that perpetuate the poverty status of the respondents.

\section{Hypothesis of the study}

$\mathrm{H}_{\mathrm{o}}$ : there is no significant relationship between farmers' characteristics and their poverty status.

\section{Methodology}

Area of study

The study was conducted in the Southern part of Kaduna State within the guinea savanna belt of Nigeria. This area, constituting the Southern senatorial zone of Kaduna State is bordered by Niger State in the South, Kaduna central senatorial zone in the north and Nassarawa State in the east. Southern Kaduna is located in the low savanna plains about $560 \mathrm{~mm}$ above sea level. The climate of the area is typically tropical with the temperature varying at different times of the year. There are two distinct seasons, the wet and dry seasons, with annual rainfall range of between $600 \mathrm{~mm}$ and $1000 \mathrm{~mm}$, making the area very productive for food crops as well as case crops like ginger.

\section{Sampling procedure and data collection}

Multistage sampling procedure was used. Three LGAs (Kechia, Jaba and Kagarko) were purposively selected, known as major areas of ginger production. Secondly, three villages from Jaba and Kagarko and two from Kachia LGAs were randomly selected. Lastly, from a sample frame of ginger farmer in the area, 440 respondents were randomly selected. Primary data for the study were generated using a structured questionnaire.

Table 1: Study Population and Sample Size

\begin{tabular}{lccc}
\hline LGA & Villages & Population of ginger farmers & Sampled respondents $(\cong \mathbf{1 0} \%)$ \\
\hline Kachia & Gumel & 501 & 50 \\
& Kachia & 617 & 62 \\
Jaba & Sumaba & 401 & 40 \\
& Kwoi & 843 & 84 \\
\multirow{3}{*}{ Kagarko } & Walijo & 480 & 48 \\
& Jere & 595 & 59 \\
& Karko & 604 & 60 \\
Total & Kenyi & 372 & 37 \\
\hline
\end{tabular}

\section{Analytical Techniques}

Both descriptive and inferential statistics were employed to analyze data and address study objectives. For the inferential statistics, poverty index, Foster-Greer-Thorbecke (FGT, 2010) and Logit regression models were applied. These are explicitly expressed as,

$\mathrm{p} \alpha=\frac{1}{\mathrm{~N}} \sum_{\mathrm{I}=\mathrm{i}}^{\alpha}\left(\frac{\mathrm{Z}-\mathrm{Yi}}{\mathrm{Z}}\right)^{\alpha}$

For poverty line index

$\mathrm{P}_{0}=\frac{\mathrm{q}}{\mathrm{N}}$

$\mathrm{P}_{0}=$ headcount index/ratio (incidence of poverty)

$\mathrm{p} 1=\frac{1}{\mathrm{~N}} \sum_{\mathrm{I}=\mathrm{i}}^{\alpha}\left(\frac{\mathrm{Z}-\mathrm{Yi}}{\mathrm{Z}}\right)^{1}$

$\mathrm{P}_{1}=$ poverty gap index (depth of poverty) 
$\mathrm{p} 2=\frac{1}{\mathrm{~N}} \sum_{\mathrm{I}=\mathrm{i}}^{\alpha}\left(\frac{\mathrm{Z}-\mathrm{Yi}}{\mathrm{Z}}\right)^{2}$

$\mathrm{P}_{2}=$ squared poverty gap index (measuring seventy of poverty)

Where

$\mathrm{Z}=$ poverty line;

$\mathrm{Y}=$ income of respondents below poverty line and

$\mathrm{N}=$ number of households.

Logit regression model was used in the study to determine the factors that influence poverty status. The model is expressed as:

$\mathrm{Y}_{\mathrm{i}}=\beta_{0}+\beta_{1} \mathrm{X}_{1}+\ldots+\beta_{\mathrm{n}} \mathrm{X}_{\mathrm{n}}$

Where:

$\mathrm{Y}=$ poverty status of farmers

$\mathrm{X}_{1}=$ age (years)

$\mathrm{X}_{2}=$ education (years)

$\mathrm{X}_{3}=$ family size (number of persons)

$\mathrm{X}_{4}=$ farm income $(N)$

$\mathrm{X}_{5}=$ farming experience (years)

$\mathrm{X}_{6}=$ non-farm income ( $\left.\#\right)$

$\mathrm{U}_{\mathrm{i}}=$ error factor

A 3-point Likert-type scale was used to appraise the severity of the constraints identified, with weightings of 3 (very severe), 2 (severe) and 1 (mild).

\section{Results and discussion}

\section{Socio-Economic characteristics of Ginger Farmers}

The distribution of the respondents based on their socio-economic characteristics is shown in Table2. The results showed that over half of the respondents $(56 \%)$ fell within the age group of 25-34 years, followed by those that fell in the age group of 35-44 years (23\%). The mean age of the sample was 32.2 years indicating that majority of the farmers were within the active and productive age which invariably ensures high productivity. This agrees with the findings of Usman et al (2016) who reported that $80 \%$ of the respondents were within the active age of 26-50 years in their study of crop farmers in Nigeria.

Table 2: Distribution of ginger farmers based on socio-economic characteristics

\begin{tabular}{|c|c|c|}
\hline Socio-Economic characteristics & Frequency $(n=440)$ & Percentage (\%) \\
\hline \multicolumn{3}{|l|}{ Age (years) } \\
\hline $15-24$ & 52 & 11.82 \\
\hline $25-34$ & 253 & 57.50 \\
\hline $35-44$ & 104 & 23.64 \\
\hline $45-54$ & 25 & 5.68 \\
\hline $55-64$ & 6 & 1.36 \\
\hline \multicolumn{3}{|l|}{ Level of education } \\
\hline None & 120 & 37.27 \\
\hline Primary & 267 & 60.88 \\
\hline Secondary & 49 & 11.14 \\
\hline Tertiary & 4 & 0.91 \\
\hline \multicolumn{3}{|l|}{ Family size (Nos) } \\
\hline $1-2$ & 9 & 2.05 \\
\hline $3-4$ & 193 & 43.86 \\
\hline $5-6$ & 232 & 52.73 \\
\hline $7-8$ & 5 & 1.14 \\
\hline $9-10$ & 1 & 0.23 \\
\hline \multicolumn{3}{|l|}{ Marital status } \\
\hline Single & 122 & 27.73 \\
\hline Married & 318 & 72.27 \\
\hline \multicolumn{3}{|l|}{ Farming experience (years) } \\
\hline$<10$ & 41 & 9.31 \\
\hline $11-20$ & 179 & 40.69 \\
\hline $21-30$ & 133 & 30.22 \\
\hline$>30$ & 87 & 19.77 \\
\hline
\end{tabular}

Source: field study, 2016

The results in Table 2 also revealed that $53 \%$ of the households had $5-6$ persons, while $43 \%$ of them had 3 
-4 persons; the average household size being 4.5 persons. On the number of dependants, results showed that $51 \%$ of the respondents had less than 4 dependents, while $27 \%$ had 4 - dependants. Only $3 \%$ had more than 10 dependants. Invariably, households with more children had fewer dependants. Evidence from Awopeju's study (2014) showed that household size was positively and significantly related to poverty depth among households in both rural and urban Nigeria. The implication is that large household size will intensify poverty depth. Similarly, results emerging from the studies of Damisa et al (2011), Asogwa et al (2012) and Omonona (2009) found evidence to affirm that large household size worsened the poverty status of households.

The result in Table 2 also showed that majority of the respondents only had primary education, representing $60 \%$, while $11 \%$ had gone up to secondary school. About $27 \%$ had no formal education. While only $1 \%$ had gone through tertiary education. According to Dunga and Sekatemet (2013), the level of education attained has been a major factor contributing to high levels of unemployment, which in turn contributes to high levels of poverty.

On marital status, results showed that majority of the ginger farmers sampled (73\%) were married while $27.7 \%$ identified as singles. In terms of years of experience, over $71 \%$ of the respondents had between 10 and 30 years of experience in ginger production, only $9.39 \%$ had less than 10 years experience. Findings have shown that farming experience is related to the age of the farmer. That is, the older a farmer is, the more likely the years of farming experience (Sabo, 2006; Ya'ashe, 2009).

\section{Measurement of poverty status of ginger farmers}

The incidence of poverty prevailing among the sampled ginger farmers was determine using the headcount index. This is the proportion of the population whose income is below the poverty line-who cannot afford to buy a basket of basic goods.

Table 3: Mean poverty estimates for the sample

\begin{tabular}{ll}
\hline Indices & Index value (\%) \\
\hline Headcount index $\left(\mathrm{P}_{0}\right)$ & 56.591 \\
Poverty gap index $\left(\mathrm{P}_{1}\right)$ & 41.717 \\
Poverty severity index $\left(\mathrm{P}_{2}\right)$ & 29.40 \\
\hline
\end{tabular}

Source: field study, 2016

Note: Poverty line assumed to be US\$1.90 (\$684) per day.

The results in Table 3 showed that majority of the sampled ginger farmers are poor considering that more than $56 \%$ of them fell below the poverty line. This is plausible and in agreement with Oke and Adeyemo (2007) who found that people working in agriculture constitute a higher proportion of the poor. Furthermore, Adekoya (2014) found that the prevalence of poverty among farm households in Ogun State was 0.781, representing 78.1 of the farm households.

The poverty gap $\left(\mathrm{P}_{1}\right)$ in Table $3(41.7 \%)$ showed the depth/intensity of poverty, among the respondents. It accounts for how poor the poor are and the index of $41.7 \%$ implies that, on the average, the sampled ginger farmer have an expenditure shortfall of about $42 \%$ of the poverty line.

The severity poverty index $\left(\mathrm{P}_{2}\right)$ for the sample was given as $29.40 \%$. This index takes into account not only the distance separating the poor from the poverty line (poverty gap), but also the inequality among the poor, giving more weighting to the very poor.

Factors influencing the poverty status of ginger farmers

The maximum likelihood estimates of the coefficients of the logit regression model for factors influencing the poverty status of the respondents are presented in Table 4.

Table 4: Maximum likelihood estimates of coefficients of logit model for factors influencing poverty status of respondents

\begin{tabular}{|c|c|c|}
\hline Variable & Coefficient & t-value \\
\hline Constant & -0.829 & $3.167 * * *$ \\
\hline Age & -0.302 & 1.557 \\
\hline Level of education & -0.109 & $2.729 * * *$ \\
\hline Dependants' ratio & 0.323 & $2.314 * *$ \\
\hline Farming experience & 0.422 & 1.589 \\
\hline Farm income & -0.399 & $4.110 * * *$ \\
\hline Non-farm income & 0.101 & 1.372 \\
\hline
\end{tabular}

Source: field study, 2016.

The results showed that three of the six exploratory variables regressed in the model were statistically significant, viz, the educational level of household head, the dependency ratio and farm income. The educational level attained by household heads had an inverse relationship with the respondents' poverty status implying that the higher the literacy status of the household head, the lower the likelihood of the household becoming poor. This is in consonance with the findings of Adekoya (2014) in Ogun State and Anyanwu (2010) who respectively 
affirmed this inverse relationship. The dependency ratio was also significant and positively related to poverty status. This is clearly in agreement with the findings of Awopeju (2014) in his study of poverty in rural urban Nigeria. The results also indicated that the poverty status of the respondents was significantly and inversely related to farm income. The regression coefficient of 0.3999 implies that a unit increase in the size of household farm income would lead to a reduction of poverty by about $40 \%$. This agrees with the findings of Omobowale (2014) on rural poverty in Nigeria.

Factors influencing the intensity of poverty among sampled ginger farmers

The estimates of the factors influencing the intensity of poverty status (Logit model) among the respondents are shown in Table 5.

Table 5: Estimates of the factors influencing the intensity of poverty among the respondents

\begin{tabular}{lll}
\hline Variable & Coefficient & t-value \\
\hline Constant & -2.221 & 1.137 \\
Age & 1.64 & 1.243 \\
Level of education & 0.115 & 1.114 \\
Dependents' ratio & $1.458^{*}$ & $3.518^{* * *}$ \\
Farming experience & 1.275 & 1.11 \\
Farm income & -1.121 & $4.024^{* * *}$ \\
Non-farm income & -0.162 & 0.853 \\
\hline
\end{tabular}

Source: field study, $2016 \quad * \mathrm{P}<0.01$

The results in Table 5 showed that only two factors, namely dependants' ratio and farm income, significantly influenced the intensity of poverty. The odds in favour of farm income reducing poverty is more than 1.5 times with a probability of 0.61 and is highly significant $(\mathrm{P}<0.01)$. These results are similar to those of Anyanwu $(2010)$ who found same variables influencing the intensity of poverty in his study.

\section{Constraints affecting ginger production in the area}

Identifying the major constraints affecting ginger production in the study area was achieved using a 3-point Likert type scale to appraise the severity of the constraints. Using a benchmark (mean) of 2, the result of Table 6 showed that the mean scores ranged from 1.92 to 2.61 .

Table 6: Distribution of respondents based on the severity of identified constraints Severity of constraints

\begin{tabular}{lllll}
\hline Constraint & $\begin{array}{l}\text { Very severe } \\
\text { (3) }\end{array}$ & $\begin{array}{l}\text { Severe } \\
\text { (2) }\end{array}$ & $\begin{array}{l}\text { Mild } \\
\text { (1) }\end{array}$ & $\begin{array}{l}\text { Mean (X) } \\
-\end{array}$ \\
\hline i. Inadequate funding/capital & 307 & 94 & 39 & 2.61 \\
ii. Inadequate supply/availability of farm inputs & 246 & 143 & 51 & 2.44 \\
iii. Poor pricing of produce & 294 & 117 & 29 & 2.60 \\
iv. Poor yield of crops & 221 & 173 & 46 & 2.39 \\
v. Delays in the supply of farm inputs \& credit & 143 & 144 & 142 & 2.00 \\
vi. Few and irregular extension/advisory visits & 245 & 128 & 67 & 2.40 \\
vii. Technical nature of improved technologies & 131 & 142 & 167 & 1.92 \\
viii. Non-membership of cooperative/farmer groups & 140 & 152 & 148 & 1.98 \\
\hline
\end{tabular}

Source: field study, 2016.

Results in Table 6 showed that inadequate funding/capital topped the list of constraints with a mean score of 2.61, followed by poor pricing of produce (2.60) and inadequate supply of farm inputs (2.44). Two of the constraints, technical nature of improved technologies (1.92) and non-membership of cooperative farmer groups (1.98), fell short of the benchmark (2) while delays in the supply of farm inputs and credit barely made the mark at 2.00. The non-delays in the supply of farm inputs and credit may be as a result of the activities of some NGOs (eg CaRE - NGO) in the area. Invariably, the more severe the constraints, the more likely they would impinge on the likelihood of ginger farmers escaping the poverty trap. These results are in agreement with the findings of Asogwa et al (2012) and Mailumo et al (2014) that identified similar constraints affecting production in their respective studies.

\section{Conclusion and recommendations}

The results of the study indicate that majority of the sampled ginger farmers fell below the poverty line of US $\$ 1.90$ (N684) per day. The poverty gap index and poverty severity index figures of $41.71 \%$ and $29.40 \%$ respectively, affirmed the precarious poverty status of the respondents. The results of the study revealed that three factors, namely educational status, dependants' ratio and farm income significantly influenced poverty status of ginger farmers $(\mathrm{P}<0.01)$. However, only the dependants' ratio and farm income were shown to significantly influence the intensity of poverty among the respondents. The determination of the factors influencing poverty status and 
intensity of poverty, as well as the identification of major constraints affecting ginger production would invariably provide the benchmark for veritable policy interventions.

The findings of this study have far-reaching implications for poverty reduction among the sampled respondents through increased ginger production and farm income. The study therefore recommends that more efforts should be geared towards the provision of adequate farm inputs and credit by government and the NGOs operating in the area. The study also encourages the formation and membership of corporative and farmer groups to enhance bargaining power and economics of scale.

\section{REFERENCES}

Adekoyo, O.A (2014) Analysis of farm household poverty status in Ogun State. Asian Economics and Financial Review.4 (3):325-340

Anyanwu, J.D. (2010). Poverty in Nigeria: a Gendered Analysis. The African Statistical Journal 11:1-15.

Asogwa, B.C, Umeh, JC, and Okwoche, V.A.(2012) Estimating the Determinants of Poverty Depth Among the Peri-urban Farmers in Nigeria. Current Research Journal of Social Sciences 4(3):201-206.

Awopeju, S.O. (2014). Determinants of Poverty Depth Among Household in Rural Urban, Nigeria. Paper Presented at the $14^{\text {th }}$ EAPI General Conference On Responsible Development in a Polytechnic World, 23-26 June, Bonn.

Bradshaw, T.K. (2008) Theories of Poverty and Anti-poverty Program in Community Development RPRC Working Paper, No.11

Damisa, M. A., Sanni, S. A., Abdoubye T, Kamara, A. Y and Ayanwale, A. (2011). Householdtypology based Analysis of livelihood strategies and poverty status in the Sudan Savannah of Nigeria: Baseline conditions. Journal of Agriculture and Environmental Studies, 2(1),: 146-160

Egbuchua, C.N and Enujeke, C.E. (2013). Growth and Yield Responses of Ginger to Three Sources of Organic Manures in a Typical Rain Forest Zone Of Nigeria. Journal of Horticulture and Forestry 5(7): 109-114

Foster, J. Greer, J. and Thorbecke (2010). The Foster- Greer- Thorbecke (FGT) Poverty Measure: 25 Years Later. Journal of Economic Inequality 8(4):491-524.

Ihuoma A.A and Dogara, M (2018).Impact of ginger production on poverty Alleviation in Kaduna State. Nigerian Journal of Economics and Finance 9(3):37-44.

KADP (Kaduna state Agriculture Development Project) (2011). Production of Ginger: An Extension Guide. Pp.8

Mailumo, S, Dawang, C and Okeke-Agulu, K (2014). Increasing Production Efficiency of Ginger for Poverty Alleviation in Kaduna State, Nigeria. A Stochastic Frontier Approach. International Journal Of Development And Sustainability.3(7):1468-1476

Masood, S.A and Nasir, I (2010). Determinants of Urban Poverty. The Case of Medium Sized City in Pakistan. Pakistan Institute of Development Economics (PIDE) Working Paper, 3-19.

MDG(Millenium Development Goal) Report (2012)

Oke, J.T. and Adeyemo, R (2007). Impact of Non-governmental Organization (NGOs) On Rural Poverty Alleviation in South Western Nigeria. International Journal Of Applied Agriculture And Agriculture Research 4(182):1-13

Omobowale, A.O.(2014) Likelihood, Agro- Ecological Zones and Poverty in Rural Nigeria. Journal of Agricultural Science 6(2):103 113.

Omonona, T.B. (2009) Quantitative Analysis of Rural Poverty in Nigeria. Strategy Support Program (SSP) brief No.17.

Sachs, J.D. (2005). The End of Poverty: Economic Possibilities of Our time. Penguin Press, New York. PP. 261.

Suhako, Y. (2007). The Role of NGOs in Rural Poverty Reduction Case of India and Indonesia. Discussion Paper No 160GSID, Nagoya University.

Thomas, S. and Canagarajah, S. (2008) Poverty in a Wealthy Economy: The Case of Nigeria. IMF Working Papers $02 / 114$.

Ugwuanyi. B.I and Chukumm, E(2013) Enhancing Rural Development in Nigeria Periscoping The Impediments And Exploring Imperative. Singaporean Journal Of Business Economics And Management Studies 1(8) 1-11.

Usman, M. N., Ibrahim, E. D., and Tanko 2 (2016) Reception and Adaptation of Crop Famers to check in Niger State, Nigeria 12 (4): 156-193.

World Bank (2015). Poverty rates and international poverty lives. World Development Indicators (WDI) World Bank, Washington DC. http://wdi.worldbank.org/filedownloadhandler.Ashx? filename $=2.8$ Pdffiletype $=$ wdistatic

Ya'aishe, M., Putai, J.A. and Petu-Ibikunle, A.M. (2009). An Economic Analysis of Cowpea production among women farmers in Askera/uba LGA, Borno State, Nigeria, African Journal of General Agriculture, 6(1):111. 